JIPSINDO No. 1, Volume 3, Maret 2016

\title{
PENELITIAN IBU RUMAH TANGGA KORBAN ALIH FUNGSI LAHAN BERBASIS LIFE SKILL
}

\author{
Tellys Corliana, Sri Giyanti \\ Fakultas Keguruan dan Ilmu Pendidikan \\ Universitas Prof Dr Hamka Jakarta \\ email: srigiyantiuhamka@gmail.com
}

\begin{abstract}
Abstrak
Perubahan sosial masyarakat tidak selalu berdampak positif bagi masyarakat luas. Terutama yang berkaitan dengan perubahan fisik seperti konversi lahan. Warga yang mengandalkan kehidupannya dari bidang pertanian, akan kehilangan pekerjaan mereka dengan pembebasan lahan untuk industri perumahan. Seperti yang terjadi di Desa Leuwinanggung, Depok. Tujuan dari pelatihan ini adalah untuk memberikan keterampilan katering untuk ibu rumah tangga yang dapat menjadi sumber kegiatan pendapatan. Dengan demikian hasil yang diharapkan adalah kemampuan untuk menjadi pengusaha katering dan makanan. Mengingat latar belakang pendidikan yang rendah metode yang kita terapkan, yaitu praktek pelatihan langsung dengan bantuan instruktur dalam membaca resep, menimbang bahan, pengolahan dan memasak dan packing. Hal lain yang kami berikan adalah untuk melatih mereka untuk membuat pembukuan sederhana. Sebelum diberikan pelatihan kejuruan, mitra juga dibentuk karakternya menjadi lebih tertib, sopan dan memahami kebersihan dan kejujuran dalam perdagangan. Hasil yang diperoleh dari pelatihan life skill ini, korban ibu-ibu rumah tangga dari konversi lahan ini memiliki keterampilan dan kreativitas dalam membuat makanan basah, roti kering dan makanan ringan dari bahan baku lokal seperti singkong, ubi dan pisang menjadi nilai ekonomi yang lebih. Empat dari 19 peserta sudah mulai menjual kue dengan penghasilan Rp 25.000 - Rp 30.000 per pendapatan hari relatif stabil jika dibandingkan dengan hasil dari pekerjaan aneh yang belum tentu jauh.
\end{abstract}

Kata Kunci: korban conversion land, life skill 


\begin{abstract}
Social change in the community do not always have a positive impact for the wider community. Especially those associated with physical changes such as land conversion. Residents who rely for their livelihood on agriculture fields, will have lost their jobs with the land acquisition for the housing industry. As happened in the village Leuwinanggung, Depok. The purpose of this training is to provide skills catering to mothers of households that can be a source of income activities. Thus the expected outcomes is the ability to be entrepreneurs catering and food. Given the low educational background of the methods that we apply, namely direct training practice with instructor assistance in reading the recipe, weigh materials, processing and cooking and packing. Another thing that we provide is to train them to make simple bookkeeping. Before being given vocational training, partners are also molded his character becomes more orderly, polite and understand cleanliness and honesty in trade. The results obtained from this life skill training, mother-housewife victim of this land conversion have the skills and creativity in making wet food, dry bread and snacks from local raw materials such as cassava, yams and bananas into more economic value. Four of the 19 participants have already started selling cakes with an income of Rp 25.000 - Rp 30,000 per day income relatively stable when compared to the results of odd jobs that are not necessarily far.
\end{abstract}

Key Word : victims of land conversion, life skill

\title{
Pendahuluan
}

Proses industrialisasi di berbagai tempat akan berpengaruh kuat terhadap tata kehidupan sosial secara keseluruhan. Hal ini disebabkan hampir di setiap masyarakat, aspek ekonomi bersifat determinan bagi pola-pola stratifikasi sosial, struktur hubungan dalam keluarga, kebijakan-kebijakan politik, arah dan sistem pendidikan masyarakat (Usman, 2006). Kasus-kasus industrialisasi di Indonesia dan kebanyakan Negara berkembang lainnya berkaitan dengan proses alih fungsi lahan pertanian menjadi kawasan industri, baik yang bergerak di bidang manufactur maupun di bidang property. Persoalannya persis sama seperti yang terjadi di Negara Barat. 
Permasalahan yang muncul yaitu a) terjadinya mobilisasi penduduk dari daerah pedesaan ke kawasan industri, sementara tidak semuanya dapat tertampung dalam lapangan kerja industri karena tidak memenuhi kualifikasi, b) mereka yang tidak tertampung memunculkan adanya dualisme ekonomi, yaitu sektor industri modern yang ditandai padat modal dan sektor ekonomi rakyat (tradisional) yang padat karya. Meskipun berdampingan seringkali sektor industri modern menjadi anak mas pemerintah, c) terjadinya benturan sosial dengan masyarakat setempat. Bibit benturan sosial antara pemerintah dan investor dengan masyarakat setempat tertanam sejak pembebasan lahan untuk kawasan industri, d) hilangnya sumber penghasilan sehingga mengharuskan mereka beralih ke jenis-jenis pekerjaan baru yang tidak dipahami sebelumnya.

Industrialisasi yang berarti pula proses perubahan lingkungan fisik dan lingkungan sosial biasanya diawali oleh perubahan alih fungsi lahan. Perubahan ini biasanya terjadi pada fungsi lahan pertanian menjadi lahan industri manufacture (pabrik) atau industri property (perumahan). Hal ini terjadi di wilayah Leuwinanggung, Cimanggis, Depok yang sebelumnya pernah kami lakukan penelitian. Pada awalnya wilayah ini merupakan wilayah potensial pertanian yang menyokong kebutuhan bahan baku pangan wilayah perkotaan seperti Jakarta berupa sayuran, buah dan rempah-rempah. Luas wilayah Leuwinanggung 380 hektar dengan jumlah penduduk 11.691 jiwa, yang terdiri dari 6.070 laki-laki dan 5.621 perempuan. Wilayah ini terbagi menjadi 13 RW dengan 2.702 kepala keluarga.Umumnya mereka bekerja sebagai petani dan pedagang.

Kelurahan Leuwinanggung berada di sebelah Timur Kota Jakarta, berada diperbatasan Jakarta dan Jawa Barat, tepatnya di 
kecamatan Tapos, kabupaten Depok, provinsi Jawa Barat. Profil penduduk Leuwinanggung berdasarkan tingkat pendidikan dapat dicermati pada tabel dibawah ini sebagai berikut :

Tabel 1. Tingkat Pendidikan

\begin{tabular}{|c|l|c|}
\hline No & \multicolumn{1}{|c|}{ Tingkat pendidikan } & Jumlah \\
\hline 1 & Belum sekolah & 1.526 orang \\
\hline 2 & Tidak tamat SD & 1.697 orang \\
\hline 3 & Tamat SD & 3.695 orang \\
\hline 4 & Tamat SLTP & 2.661 orang \\
\hline 5 & Tamat SLTA & 1.752 orang \\
\hline 6 & Tamat Akademi & 238 orang \\
\hline 7 & Tamat PT & 121 orang \\
\hline
\end{tabular}

Sumber : Kantor kelurahan Leuwinanggung

Mereka yang tergusur umumnya tetap ada di Leuwinanggung, hanya mereka bergeser lebih ke pinggir dan banyak terpusat di RW 06 dan 11, setelah terjadi penggusuran para warga ini hanya memiliki lahan 100 - 200 m persegi saja, yang artinya tidak lagi cukup untuk bertani yang dapat digunakan sebagai sumber penghasilan utama keluarga. Mereka yang tergusur tersebut beralih pekerjaan sebagai buruh, ngojek, pembantu rumah tangga, satpam perumahan. Tingkat pendidikan mereka yang umumnya hanya lulus SD dan SMP menyebabkan mereka hanya bisa memasuki lapangan kerja dengan penghasilan yang rendah.

Kondisi yang lebih memprihatinkan terjadi pada ibu rumah tangga yang tidak memiliki ketrampilan, yang awalnya hanya sebagai petani membantu suami mereka, saat ini mereka hanya sebagai buruh menyiang sereh dan lengkuas pada pemilik tanah yang bukan penduduk asli atau pendatang. Sebagai buruh menyiang sereh dan lengkuas mereka mendapat upah Rp 100,-/ kg. Per hari minimal mereka mendapat upah Rp 2000,- 
(tergantung banyaknya yang bisa disiangi). Sebagian lagi sebagai pembantu rumah tangga dengan penghasilan Rp 300.000,- hingga Rp 500.000,-/bulan, atau berjualan makanan tanpa kemampuan wirausaha yang memadai dengan keuntungan sekitar Rp 3000,-Rp 4000,- per hari. Sementara suami mereka setelah tidak memiliki lahan ada yang bekerja sebagai penyojek dengan ratarata penghasilan sekitar $\operatorname{Rp} 25.000,-$ /hari, sebagai buruh bangunan dengan penghasilan Rp 50.000,-/hari atau sebagai pedagang keliling dengan penghasilan rata-rata $\mathrm{Rp}$ 25.000,hingga Rp 30.000,-/hari yang hanya cukup untuk makan seharihari. Sedangkan sebagaian besar keluarga ini masih memiliki anak yang masih sekolah yang tentunya masih banyak membutuhkan biaya.

Secara sumber daya alam sebenarnya wilayah ini banyak menghasilkan pisang, umbi-umbian dan rempah yang dapat diolah menjadi produk jadi yang layak jual dengan hasil income yang lebih baik dari pada sekedar direbus atau jual apa adanya. Berdasarkan hasil kajian awal tersebut, kami berupaya untuk dapat mengentaskan mereka menjadi wirausaha dengan memanfaatkan potensi alam yang ada dengan cara memberikan ketrampilan membuat makanan dan pengetahuan wirausaha. Hal ini sesuai dengan keinginan mereka berdasarkan hasil wawancara kami untuk dapat memiliki pekerjaan yang dapat dipadukan dengan kegiatan sehari-hari mereka sebagai ibu rumah tangga seperti halnya ketika masih memiliki lahan pertanian.

Berbagai keahlian atau kecakapan sangat diperlukan dalam kehidupan bermasyarakat. Oleh karena itu, pendidikan yang berorientasi kepada masyarakat harus mampu mengedepankan pendidikan yang mempunyai dasar pada kecakapan hidup. Upaya penumbuhan kecakapan hidup dalam pendidikan pada jenis, 
jenjang dan satuan pendidikan atau pelatihan yang disesuaikan dengan tujuan pendidikannya dapat diselenggarakan dengan pola broad based education (BBE).

Kecakapan hidup (life skills) merupakan kecakapan untuk memecahkan masalah secara inovatif dengan menggunakan fakta, konsep, prinsip atau prosedur yang telah dipelajari. Pemecahan masalah tersebut dapat berupa proses maupun produk yang bermanfaat untuk mempertahankan, meningkatkan, atau memperbaharui hidup dan kehidupan masyarakat. Life skills memiliki makna yang lebih luas dari kecakapan kerja tertentu (vocational skills). Life skills lebih tepat diartikan sebagai kecakapan hidup. Pengertian kecakapan hidup di sini, tidak semata-mata berarti memiliki kemampuan tertentu saja, namun ia harus memiliki kompetensi dasar pendukungnya, seperti membaca, menulis, menghitung, merumuskan dan memecahkan masalah, mengelola sumber daya, bekerja dalam tim atau kelompok, terus belajar di tempat bekerja, mempergunakan teknologi, dan lain sebagainya.

Kecakapan hidup yang berhubungan dengan hidup yaitu kecakapan yang dibutuhkan agar seseorang dapat tetap bertahan hidup dan berkembang secara layak, memenuhi syarat kesehatan, kemanusiaan, kesusilaan dan kehormatan. Untuk tetap bertahan hidup, terlebih untuk berkembang, seseorang tentu harus kreatif dalam memecahkan berbagai persoalan yang muncul ke permukaan dengan segenap kemampuan dan keahliannya. Apabila seseorang terbiasa menghadapi tantangan dalam memecahkan persoalan hidup, sekecil apapun, maka ia tentu akan mempunyai pengalaman dalam mengatasi persoalan. Sehingga suatu saat ia menghadapi persoalan yang sejenis, ia akan dapat memecahkannya karena telah terlatih, terbiasa dan 
ahli.

Berdasarkan kondisi dan masalah yang telah dikemukakan di atas, maka penerapan Ipteks bagi masyarakat khususnya ibu rumah tangga yang mengalami penggusuran alih fungsi lahan dirasa tepat dengan mengajarkan ketrampilan yang sesuai dengan sumber daya alamnya. Hal ini dikarenakan mereka, khususnya ibu rumah tangga yang kehilangan lahannya memiliki pendidikan yang rendah dan tidak memiliki ketrampilan lain selain bertani. Pendidikan kecakapan hidup (life Skills) dengan pendekatan berbasis pada kebutuhan masyarakat luas (broad based education) adalah solusi sesuai untuk memberikan atau meningkatkan ketrampilan yang dapat dijadikan sumber penghasilan. Mencermati permasalahan di atas, maka diperlukan pendidikan non formal untuk masyarakat yang dapat meningkatkan kemampuan dan ketrampilan hidup sehari-hari sebagai modal berharga untuk kehidupan saat ini dan generasi mereka selanjutnya.

Pemberian pendidikan kecakapan hidup ini bertujuan untuk memberikan kemandirian kepada mitra sebagai berikut :

1. Memberikan skill kepada ibu-ibu rumah tangga korban alih fungsi lahan di lingkungan Leuwinanggung yang umumnya berpendidikan rendah dan tidak memiliki ketrampilan di luar pertanian.

2. Memberikan kepekaan kepada mitra terhadap peluang ekonomi yang dapat dimanfaatkan disekitar mereka.

3. Memberikan ketrampilan dalam mengolah bahan baku yang ada menjadi bernilai ekonomis.

4. Memberikan ketrampilan pada mitra untuk dapat dapat ikut bersaing di ranah bisnis dengan memberikan ketrampilan membuat makanan layak jual dengan packing yang menarik. 


\section{Metode Penelitian}

Untuk lebih mengintegrasikan kegiatan tersebut dengan warga yang memang membutuhkan, maka warga diperlakukan sebagai partisipan sebagai berikut:

1. Warga belajar diminta menentukan dan menyiapkan tempat kegiatan yang dirasa kondusif untuk proses pembelajaran.

2. Warga belajar menentukan jenis makanan yang ingin dipelajari secara professional dan layak jual berdasarkan bahan baku setempat.

3. Warga belajar membentuk sendiri kelompok belajarnya berdasarkan arahan dari fasilitator, agar lebih nyaman dalam proses pembelajaran.

4. Warga belajar menyiapkan alat-alat pribadi yang mungkin dapat digunakan seperti wajan, kompor, pisau, wadah dan sebaginya.

Mengingat warga binaan adalah kelompok ibu-ibu rumah tangga yang memiliki tingkat pendidikan rendah dan tidak memiliki latar belakang ketrampilan yang memadai maka ada beberapa langkah yang kami lakukan, sebagai berikut :

\section{Metode pendekatan}

Metode pendekatan sebelum melangkah pada tahap pelatihan yang kami lakukan yaitu pendekatan secara personal. Kami duduk bersama untuk saling mengenal dan bertukar informasi serta pengalaman. Hal ini dimaksudkan agar tidak terjadi gap atau jarak sosial yang akan memunculkan rasa enggan dan sungkan dari warga. Kedekatan yang terwujud diantara warga binaan dan pelaku pemberdayaan akan memudahkan keterbukaan warga untuk menyampaikan kendala-kendala yang mereka hadapi dan menerima pelatihan yang akan diberikan dengan senang. 


\section{Pendidikan Karakter}

Tadkiratun Musfiroh (2008: 27) menjelaskan bahwa karakter mengacu pada serangkaian sikap perilaku (behavior), motivasi (motivations), dan keterampilan (skills), meliputi keinginan untuk melakukan hal yang terbaik.Maksudnya bahwa pendidikan karakter adalah usaha yang sengaja dilakukan untuk membantu masyarakat, memahami perilaku orang lain, peduli dan bertindak serta memiliki ketrampilan atas nilai-nilai etika.

Tujuan pendidikan watak atau karakter menurut Darmiyati Zuchdi (2008: 39) untuk mengajarkan nilai-nilai tradisional tertentu, nilai-nilai yang diterima secara luas sebagai landasan perilaku yang baik dan bertanggung jawab.Nilai-nilai ini digambarkan sebagai perilaku moral. Proses pembelajaran karakter lebih diarahkan pada aspek pengetahuan, ketrampilan dan perilaku, seperti yang diungkapkan Barth (1990: 254) terdapat tiga aspek dalam pembelajaran yang harus dicapai yaitu; "a) knowledge, which is a body of fact and principles; b) skill, which is acquiring an ability through experience or training; c) attitude, which is one's opinion, feeling or mental set as demonstrated by one's action".

Pernyataan di atas dapat dijelaskan bahwa tiga aspek dalam pembelajaran meliputi a) pengetahuan, adalah bentuk dari prinsip dan fakta; b) ketrampilan, adalah pemerolehan kemampuan melalui pelatihan atau pengalaman; c) sikap, adalah suatu pendapat, perasaan atau mental seseorang yang ditunjukkan oleh tindakan.

Pendidikan karakter ini dilakukan dengan pemberian nasehat dan contoh kasus dengan bahasa yang mereka pahami. Perubahan karakter yang kami lakukan, antara lain: 
a) Etika

Seperti sopan santun dalam kebersamaan, dalam tutur kata dan berpenampilan. Hal ini kami lakukan karena mereka cederung senang bergunjing dan menyindir sesamanya, menggunakan pakaian yang kurang sopan. Perilaku tersebut merupakan perilaku yang tidak santun dan tidak produktif.

b) Menumbuhkan Motivasi

Latar belakang petani yang selalu dimanjakan oleh ketersediaan alam membuat warga khususnya perempuan di wilayah suburban kurang memiliki motivasi untuk maju dan produktif secara ekonomi. Metode yang kami lakukan untuk hal ini dengan menghadirkan warga binaan dari komunitas lain dengan kondisi sosial (status ekonomi) asal yang relatif sama untuk menceritakan keberhasilannya di bidang usaha rumahan.

c) Menumbuhkan rasa disiplin

Kebiasaan warga yang tidak tertib dalam mengelola waktu juga perlu diubah sehingga mereka lebih tertib.

d) Menumbuhkan rasa percaya diri

Tingkat pendidikan yang rendah umumnya membentuk rasa percaya diri yang rendah pula. Untuk itu kami juga berusaha menumbuhkan rasa percaya diri mereka dengan memberikan contoh warga binaan lain dengan latar belakang pendidikan yang sama tetapi dapat berhasil secara ekonomi.

e) Tangguh

Menanamkan keuletan untuk tidak mudah berputus asa dalam berusaha.

\section{Pembentukan Kognitif}

Tahap selanjutnya yaitu pembentukan kognitif . Berdasarkan pengalaman yang telah kami lakukan, setelah terbentuk karakter yang lebih baik dari warga, maka proses pembelajaran yang 
berkaitan dengan kognitif, pengetahuan dapat dimulai. Dalam hal ini, jenis ketrampilan yang diberikan tentunya harus disesuaikan dengan lingkungan, sumber daya dan kedekatan kemampuan yang mereka miliki.

4. Psikomotorik (Ketrampilan)

Mengingat latar belakang pendidikan warga yang rendah maka metode yang kami lakukan tidak dengan memberi banyak teori. Metode yang kami lakukan yaitu dengan cara praktek langsung sambil menjelaskan step by step yang harus dilakukan dipandu langsung oleh instruktur.

Untuk kecakapan boga, mengingat mereka tidak terbiasa membaca resep, maka perlu diajarkan atau dipandu bagaimana cara membaca resep, memilih bahan, menimbang bahan dan cara mengadoni adonan. Dalam hal ini instruktur mencontohkan langsung kemudian diikuti peserta.

Demikian juga bagaimana cara memasak, peserta diberikan contoh secara langsung praktek bagaimana cara menggoreng, mengopen atau memanggang, mengukus dan sebagainya

\section{Hasil Penelitian}

Kegiatan penelitian ini dilakukan dalam empat tahapan yang dikelompokkan berdasarkan jenis makanan yang dibuat dan tingkat kesulitannya, yaitu :

1. Tahap pertama membuat makanan atau kue basah yang terbuat dari ubi, singkong dan pisang.

2. Tahap kedua membuat jenis makanan peragian (roti) dan cake dengan bahan dasar ubi, singkong dan pisang

3. Tahap ketiga membuat makanan serba kering baik digoreng maupun di panggang dengan bahan baku ubi, singkong dan pisang 
4. Tahap keempat menjelaskan kepada mitra cara membukuan sederhana, menentukan harga jual dan kewirausahaan.

Pelatihan tahap pertama dilaksanakan pada tanggal 14 Mei 2015. Kegiatan dilaksanakan di rumah ketua RW 06, kelurahan Leuwinanggung, kecamatan Tapos, Depok. kegiatan dilakukan dari jam 8.00-16.00. pelatihan diawali dengan persiapan peserta dan kelengkapannya. Kemudian penjelasan bahan baku dan alternatif bahan pengganti bila tidak tersedia. Resep yang dipelajari pada tahap pertama yaitu membuat Getuk Singkong Gulung Rainbow, Cake Singkong Karamel Tradisional, Kue Lumpur Ubi Kuning, Klepon Ubi Ungu, dan Pisang Goreng Pasir.

Peserta pada pelatihan ini mendapatkan pendampingan dari mulai membaca resep, menakar bahan baku, mengadon dan memasak. Dengan tehnik pelatihan semacam ini peserta lebih mudah mengingat dan memahami langkah-langkah yang benar. Resep yang diberikan pada tahap pertama merupakan kudapan basah yang relatif lebih mudah dan lebih familier buat mereka.

Pada pelatihan tahap pertama berdasarkan hasil evaluasi hasil menunjukkan bahwa mitra atau peserta pelatihan dapat menyerap dengan baik. Hal ini menunjukan bahwa resep yang diberikan pata tahap pertama cukup mudah untuk difahami. Resep yang diberikan pada tahap pertama merupakan resep kudapan atau kue basah seperti klepon ubi, cake karamel singkong, kue lumpur, getuk pelangi dan pisang goreng panir. Tahap pertama memang sengaja kami berikan resep yang masih sederhana yang tidak terlalu asing buat mereka.

Pelatihan tahap kedua, dilakukan pada tanggal 13 Juni 2015. Resep yang dipelajari pada tahap kedua yaitu membuat Cup Cake Cokelat Singkong, Donat Singkong, Kue Bolu Pisang Spesial Keju, Roti Ubi Jalar. Roti ubi jalar merupakan resep yang dapat 
dimofikasi menjadi berbagai macam roti dengan cara memasak yang berbeda dan dengan isi yang beragam. Tahap kedua meningkat pada tingkat kesulitan yang lebih tinggi dibandingkan tahap pertama. Kesulitan pada tahap ini berkaitan dengan cara mengocok dan memanggang cake yang akan berpengaruh pada hasil cake yang mengembang atau bantat. Kesulitan yang lain pada tahap ini yaitu mengadon roti agar bisa mengembang dengan baik.

Berdasarkan evaluasi hasil pada tahap kedua ternyata mitra atau peserta banyak yang belum bisa menguasai cara membuat cake dan roti sehingga hasil pelatihan menunjukan cake yang tidak mengembang sempurna atau ada yang bantat, begitu juga dengan roti yang dihasilkan ada yang tidak mengembang dengan baik. Pada pelatihan tahap dua ini peserta mulai dikenalkan tingkat kreatifitas yang lebih rumit yaitu memodifikasi adonan roti dengan tambahan umbi-umbian dalam berbagai variasi yaitu digoreng (roti isi dengan variasi ayam, coklat dll, donat), dikukus (seperti pau) dan dipanggang seperti umumnya roti. Kurang optimalnya hasil pada tahap kedua dapat dimaklumi dari latar belakang mereka yang hanya sebagai ibu rumah tangga yang memiliki pendidikan yang rendah.

Pelatihan tahap ketiga dilakukan dilakukan pada tanggal 14 Juni 2015. Resep yang dipelajari pada tahap kedua yaitu membuat Keripik Pisang Goreng Tepung, Singkong Kering Balado, Stik Ubi Ungu, Ubi Kering Balado, Kue Kering Ubi Bulat, Kue kering Pisang. Pada tahap ini mitra diberikan ketrampilan makanan kering baik yang digoreng atau dioven dengan berbahan dasar ubi, singkong, dan pisang.

Pada pelatihan tahap tiga ini peserta diajarkan berkreatifitas dalam membuat kue kering dengan bahan ubi, singkong atau 
pisang. Ketrampilan ini diharapkan dapat membantu mitra untuk menjadikannya suatu usaha yang simpel, bisa dijual dengan waktu yangt relatif lebih lama daripada jenis makanan basah.

Berdasarkan evaluasi pelatihan tahap tiga, menjelaskan bahwa mitra pada umumnya masih mengalami kesulitan dalam hal memanggang kue kering. Masih ada beberapa kelompok yang hasil panggangannya tidak kering sempurna hasilnya atau kurang renyah. Tetapi untuk kue kering yang digoreng seperti keripik pisang, kering ubi, stik ubi dan singkong balado mereka sudah berhasil dengan baik.

Pelatihan tahap empat dilakukan pada tanggal 15 Mei 2015. Pelatihan tahap keempat agak berbeda dengan tahap-tahap sebelumnya. Pada tahap ini peserta tidak melakukan praktek membuat makanan tetapi pemberian materi tentang pentingnya kewirausahaan dan bagaimana membuat pembukuan sederhana. Pada umumnya pedagang pemula dari kalangan ibu rumah tangga tidak pernah memisahkan catatan dagangan dengan kebutuhan sehari-hari sehingga seringkali merugi dan tidak dapat meneruskan usahanya. Oleh karena itu hal ini penting diberikan kepada peserta. Pengetahuan kewirausahaan diharapkan dapat membantu memotivasi peserta untuk mulai berjualan.

\section{Simpulan}

Setelah melakukan kegiatan pengabdian masyarakat pada komunitas ibu rumah tangga di lingkungan RW 6 kelurahan Leuwinanggung, dapat disimpulkan: 
JIPSINDO No. 1, Volume 3, Maret 2016

1. Adanya kemajuan yang signifikan dari mitra setelah kegiatan dilakukan ada beberapa peserta yang sudah mulai berdagang makanan.

2. Kegiatan pendampingan masyarakat tidak dapat dilakukan hanya satu kali saja, tetapi memerlukan pendampingan yang intens sehingga akan terbentuk interaksi yang baik antara mitra dan fasilitator yang akan berdampak pada keberhasilan proses transformasi pengetahuan dan skill.

3. Pendekatan yang digunakan terhadap mitra harus dengan pendekatan yang disiplin dan tertib karena kebiasaan budaya mitra yang pasrah dan apatis terhadap perubahan diri.

\section{DAFTAR PUSTAKA}

Sunyoto Usman,2006, Pembangunan dan Pemberdayaan Masyarakat, Yogyakarta : Pustaka Pelajar.

Ditjen PLS, 2003. Program Life Skill Melalui Pendekatan Broad Base Education (BBE). Jakarta: Direktorat Tenaga Tehnis Depdiknas 